Wahyudin, A. • T. Nurmala • R. D. Rahmawati

\title{
Pengaruh dosis pupuk fosfor dan pupuk organik cair terhadap pertumbuhan dan hasil kacang hijau (Vigna radiata L.) pada ultisol Jatinangor
}

\section{The effect of phosphor and liquid organic fertilizer to plant growth and mung bean (Vigna radiata L.) yield on ultisols Jatinangor}

Diterima : 15 September 2015/Disetujui : 15 Oktober 2015 / Dipublikasikan : Oktober 2015

CDepartment of Crop Science, Padjadjaran University

\begin{abstract}
The objective of the experiment was to determine the dosage of phosphorus fertilizer and liquid organic fertilizer on the growth and yield of mungbean (Vigna radiata L.). The experiment conducted at the Experimental Station of The Agricultural Faculty, Universitas Padjadjaran, West Java. A randomized block design (RBD) was used in this experiment with nine treatments and three replications. The several treatment was applied namely $50 \mathrm{~kg} \mathrm{ha}^{-1}$ phosphorus fertilizer + O L ha-1liquid organic fertilizer, $50 \mathrm{~kg} \mathrm{ha}^{-1}$ phosphorus fertilizer $+4 \mathrm{~L}$ ha $^{-1}$ liquid organic fertilizer, $50 \mathrm{~kg} \mathrm{ha}^{-1}$ phosphorus fertilizer $+8 \mathrm{~L} \mathrm{ha}^{-1}$ liquid organic fertilizer, $75 \mathrm{~kg} \mathrm{ha}^{-1}$ phosphorus fertilizer + O L ha- ${ }^{-1}$ liquid organic fertilizer, $75 \mathrm{~kg}$ ha $^{-1}$ phosphorus fertilizer $+4 \mathrm{~L} \mathrm{ha}^{-1}$ liquid organic fertilizer, $75 \mathrm{~kg} \mathrm{ha}^{-1}$ phosphorus fertilizer $+8 \mathrm{~L} \mathrm{ha}^{-1}$ liquid organic fertilizer, $100 \mathrm{~kg}^{\mathrm{h}} \mathrm{a}^{-1}$ phosphorus fertilizer + O L ha-1 liquid organic fertilizer, $100 \mathrm{~kg}$ ha $^{-1}$ phosphorus fertilizer $+4 \mathrm{~L} \mathrm{ha}^{-1}$ liquid organic fertilizer, $100 \mathrm{~kg} \mathrm{ha}^{-1}$ phosphorus fertilizer $+8 \mathrm{~L} \mathrm{ha}^{-}$ 1 liquid organic fertilizer. The results of this experiment showed that the treatment of $50 \mathrm{~kg}$ phosphorus fertilizer and $8 \mathrm{~L} \mathrm{ha}^{-1}$ liquid organic fertilizer was significience the grain weight per plot of 298,68 gr and average yield per hectare of 0,99 t ha $^{-1}$.
\end{abstract}

Keywords: Mungbean · Phosphorus fertilizer . Liquid organic fertilizer

\footnotetext{
Dikomunikasikan oleh A. W. Irwan

Wahyudin, A. ${ }^{1}$. T. Nurmala ${ }^{1}$. R. D. Rahmawati ${ }^{2}$

1 Dept. Budadaya Pertanian Fakultas Pertanian Unpad

2 Alumni Program Sarjana Agroteknologi Unpad

Korespondensi : agus.wahyudin@unpad.ac.id
}

Sari Percobaan ini bertujuan untuk mengetahui pengaruh dosis pupuk fosfor dan pupuk organik cair terhadap pertumbuhan dan hasil tanaman kacang hijau (Vigna radiata L.). Percobaan dilaksanakan di kebun percobaan Fakultas Pertanian Universitas Padjadjaran, Jatinangor, Jawa Barat. Rancangan percobaan yang digunakan dalam penelitian ini adalah Rancangan Acak Kelompok (RAK) dengan sembilan perlakuan dan diulang tiga kali yaitu $50 \mathrm{~kg} \mathrm{ha}^{-1}$ pupuk fosfor $+\mathrm{O} \mathrm{L} \mathrm{ha-1}$ pupuk organik cair, $50 \mathrm{~kg} \mathrm{ha}{ }^{-1}$ pupuk fosfor $+4 \mathrm{~L} \mathrm{ha}^{-1}$ pupuk organik cair, $50 \mathrm{~kg} \mathrm{ha}^{-1}$ pupuk fosfor $+8 \mathrm{~L}$ ha $^{-1}$ pupuk organik cair, $75 \mathrm{~kg} \mathrm{ha}^{-1}$ pupuk fosfor + O L ha-1 pupuk organik cair, $75 \mathrm{~kg} \mathrm{ha}^{-1}$ pupuk fosfor $+4 \mathrm{~L} \mathrm{ha}^{-1}$ pupuk organik cair, $75 \mathrm{~kg} \mathrm{ha}^{-1}$ pupuk fosfor $+8 \mathrm{~L} \mathrm{ha}^{-1}$ pupuk organik cair, 100 $\mathrm{kg} \mathrm{ha}^{-1}$ pupuk fosfor $+\mathrm{O} \mathrm{L} \mathrm{ha}^{-1}$ pupuk organik cair, $100 \mathrm{~kg} \mathrm{ha}^{-1}$ pupuk fosfor $+4 \mathrm{~L} \mathrm{ha}^{-1}$ pupuk organik cair, $100 \mathrm{~kg} \mathrm{ha-1}$ pupuk fosfor $+8 \mathrm{~L} \mathrm{ha}^{-1}$ pupuk organik cair. Hasil percobaan menunjukkan bahwa perlakuan pupuk fosfor $50 \mathrm{~kg}$ dan pupuk organik cair 8 Lha $^{-1}$ menghasilkan bobot biji per petak sebesar 298,68 gr dan hasil ratarata per hektar sebesar $0,99 \mathrm{t} \mathrm{ha}^{-1}$.

Kata kunci : Kacang hijau · Pupuk fosfor . Pupuk organik cair

\section{Pendahuluan}

Kacang hijau merupakan salah satu bahan pangan yang banyak dibudidayakan beberapa negara Asia seperti Indonesia, Thailand, Filipina dan India. Tanaman ini, termasuk tanaman yang banyak dibutuhkan oleh masyarakat karena kegunaan dan rasanya yang enak. Di Indonesia, kacang hijau menempati posisi ketiga sebagai 
tanaman kacang-kacangan yang banyak dibudidayakan setelah kedelai dan kacang tanah. Kacang hijau memiliki kelebihan yaitu, dapat tahan pada kekeringan dan dapat tumbuh pada kondisi tanah yang kurang subur.

Permintaan untuk tanaman kacang hijau belum mencapai titik jenuh, hal ini dilihat dari permintaan yang setiap tahun terus meningkat, namun permasalahan yang dihadapi pada budidaya kacang hijau di Indonesia antara lain rendahnya produksi dan produktivitas.Kendala tersebut dapat dikurangi dengan pemakaian bibit unggul dan perbaikan teknologi. Salah satu bibit unggul yang bisa digunakan adalah kacang hijau varietas Vima-1 yang memiliki kelebihan umur genjah dan tahan penyakit embun tepung.

Selain itu kendala yang dihadapi adalah tidak terpenuhinya areal pertanaman yang dikehendaki oleh kacang hijau yakni tanah yang subur, gembur dan banyak mengandung bahan organik. Tanah yang tergolong kurang subur salah satunya adalah tanah Ultisols yang memiliki beberapa permasalahan dalam pemanfaatannya yakni ketersediaan P dalam tanah rendah.

Pemupukan dengan fosfor merupakan salah satu cara mengelola tanah Ultisols, karena disamping kadar $\mathrm{P}$ rendah, juga terdapat unsurunsur yang dapat menjerap fosfor yang ditambahkan. Menurut penelitian pemberian fosfor untuk kacang hijau telah berhasil meningkatkan hasil kering panen, jumlah polong per tanaman, biji per polong, bobot 1000 butir, hasil biji dan biomassa total (Mitra et al., 1999), sedangkan tidak adanya penambahan $\mathrm{P}$ pada kacang hijau pada akhirnya akan menurunkan hasil dan kualitas tanaman.

Menurut hasil penelitian bahwa sebagian besar lahan pertanian intensif telah mengalami penurunan produktivitas lahan, terutama terkait dengan sangat rendahnya kandungan C-organik dalam tanah yaitu sekitar $<2 \%$, sedangkan untuk memperoleh produktivitas optimal dalam budidaya dibutuhkan C-organik lebih dari $2 \%$ (Hartatik dan Setyorini, 2012). Salah satu cara meningkatkan kandungan C-organik adalah dengan penambahan bahan organik yang dapat diaplikasikan melalui pupuk organik dan jenis pupuk yang digunakan dapat berbentuk padat ataupun cair.

Pupuk organik cair merupakan pupuk yang diperoleh dari hasil pelarutan sejumlah mikroba dan unsur dari bahan organik yang telah mengalami proses fermentasi padat, kemudian dilanjutkan dengan proses fermentasi secara aerob atau anaerob. Pemberian Pupuk Organik Cair pada kacang hijau dapat membantu menyuplai unsur hara organik yang dibutuhkan oleh kacang hijau dalam proses pertumbuhan hingga proses pembentukan polong isi.

Menurut penelitian Renasari,dkk (2013) pemberian pupuk organik cair pada dosis $10 \mathrm{cc} / \mathrm{L}$ pada tanaman kacang hijau berpengaruh nyata terhadap peningkatan jumlah cabang per tanaman, berat 100 biji dan hasil polong per tanaman.

Penelitian ini bertujuan untuk memperoleh kombinasi yang tepat mengenai penambahan pupuk fosfor dan pupuk organik cair yang mempunyai pengaruhnya paling baik terhadap pertumbuhan dan hasil tanaman kacang hijau.

\section{Bahan dan Metode}

Percobaan dilaksanakan di Kebun Percobaan Ciparanje, Fakultas pertanian Universitas Padjadjaran Jatinangor, Kabupaten Sumedang, Jawa Barat yang berada pada ketinggian tempat 763 mdpl dengan tipe curah hujan $C_{3}$ menurut klasifikasi Oldeman dan jenis tanah Ultisol. Penelitian ini dimulai pada bulan Mei 2014 sampai dengan bulan Juli 2014.

Benih kacang hijau kultivar Vima-1 yang digunakan berasal dari Balai Penelitian Tanaman Kacang-kacangan dan Umbi-umbian, Malang. Pupuk N, P, K Tunggal (Urea $46 \%$ N, SP-36 $36 \%$ $\mathrm{P}_{2} \mathrm{O}_{5}, \mathrm{KCl} 60 \% \mathrm{~K}_{2} \mathrm{O}$ ), Pupuk organik Cair. Pestisida yang digunakan adalah insek-tisida dengan bahan aktif lamda sihalotrin dengan konsentrasi $2,5 \mathrm{ml} \mathrm{L}^{-1}$, fungsida berbahan aktif mankozeb $80 \%$ dengan konsentrasi $2 \mathrm{~g} \mathrm{~L}^{-1}$ dan Furadan.

Penanaman kacang hijau dilakukan dengan sistem tugal sebanyak 2 biji/lubang dengan kedalaman 3-5 cm dan jarak tanam $25 \times 25 \mathrm{~cm}$. Pemberian pupuk $\mathrm{N}$ diberikan sebanyak 2 kali yaitu pada awal tanam sebanyak $1 / 3$ dosis pupuk, pemupukan kedua sebanyak $2 / 3$ dosis pupuk $N$, Pupuk P dan K diberikan pada saat tanam.

Pupuk organik cair diberikan dengan interval memupukan selama 2 minggu, yaitu pada saat tanaman berumur $2 \mathrm{mst}, 4$ mst dan 6 mst dengan dosis sesuai perlakuan. Pupuk organik cair diencerkan dengan 1 liter air. Pupuk diaplikasikan dengan cara disiramkan pada setiap lubang tanam kacang hijau dengan dosis sesuai perlakuan.

Rancangan percobaan yang digunakan adalah Rancangan acak Kelompok (RAK) dan 
terdiri dari 9 perlakuan, dengan 3 kali ulangan yang terdiri dari : (A) $50 \mathrm{~kg}$ SP-36 ha-1+0 $0 \mathrm{~L} \mathrm{ha}^{-1}$

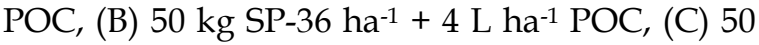
kg SP-36 ha-1+ $8 \mathrm{~L} \mathrm{ha}^{-1}$ POC, (D) 75 kg SP-36 ha-1 + $0 \mathrm{~L} \mathrm{ha}^{-1}$ POC, (E) $75 \mathrm{~kg} \mathrm{SP}-36 \mathrm{ha}^{-1}+4 \mathrm{~L} \mathrm{ha}^{-1}$ POC, (F) 75 kg SP-36 ha-1+ $8 \mathrm{~L} \mathrm{ha}^{-1}$ POC, (G) 100 kg SP-36 ha-1 +0 L ha $^{-1}$ POC, (H) 100 kg SP-36 ha $^{-1}+4 \mathrm{~L} \mathrm{ha}^{-1}$ POC, (I) $100 \mathrm{~kg}$ SP-36 ha-1+ $8 \mathrm{~L} \mathrm{ha}^{-1}$ POC. Uji statistik yang digunakan adalah uji $\mathrm{F}$ dilanjutkan dengan uji jarak berganda Duncan pada taraf uji $5 \%$.

Pengamatan komponen pertumbuhan meliputi tinggi tanaman dan indeks luas daun. Pengamatan komponen hasil dan hasil meliputi jumlah cabang produktif, jumlah polong isi per tanaman,jumlah polong hampa per tanaman, jumlah biji per polong, rata-rata bobot 100 butir, bobot biji per tanaman, bobot biji per petak, indeks panen.

\section{Hasil dan Pembahasan}

Berdasarkan hasil analisis tanah sebelum percobaan, menunjukkan bahwa Ultisol memiliki tingkat kemasaman sebesar 5,67 dengan kriteria agak masam dan tingkat kemasaman potensial $(\mathrm{pH} \mathrm{KCl}$ ) sebesar 4,41. Kandungan $\mathrm{C}$ organik dengan kriteria rendah yaitu sebesar 1,16 \%, N total sebesar $0,26 \%$, kandungan $\mathrm{C} / \mathrm{N}$ tergolong sangat rendah yaitu 4. Kandungan $\mathrm{P}_{2} \mathrm{O}_{5}$ total dengan kriteria sangat rendah yaitu $9,82 \mathrm{mg} / 100 \mathrm{~g}$, $\mathrm{K}_{2} \mathrm{O}$ total $(13,43 \mathrm{mg} / 100 \mathrm{~g}), \mathrm{P}_{2} \mathrm{O}_{5}$ tersedia dengan kriteria rendah (6,13 ppm), kejenuhan basa dengan kriteria sedang $(52,47 \%)$, Fe total dengan kriteria tinggi (70625,93 ppm).

Curah hujan selama percobaan pada bulan Mei 2014 sebesar 31,5 mm, bulan Juni sebesar $104,5 \mathrm{~mm}$ dan bulan Juli sebesar 101,5 mm. Kebutuhan air untuk tanaman kacang hijau hanya kritis pada awal petumbuhannya hingga fase pembungaan atau selama 30 hari. Kebutuhan minimalnya pada masa kritis setara dengan curah hujan $100 \mathrm{~mm}$ per bulan. Curah hujan pada saat awal percobaan kurang mendukung untuk pertumbuhan optimal tanaman kacang hijau, curah hujan pada bulan Mei tergolong sangat rendah hal ini sangat berpengaruh pada pertumbuhan tanaman.

Suhu udara rata-rata selama percobaan pada bulan Mei 2014 sebesar $23{ }^{\circ} \mathrm{C}$, bulan Juni 2014 sebesar $23,2^{\circ} \mathrm{C}$ dan bulan Juli 2014 sebesar $22^{\circ} \mathrm{C}$. Keadaan iklim yang optimum untuk tanaman kacang hijau adalah daerah yang memiliki suhu
25-27 ${ }^{\circ} \mathrm{C}$, sedangkan suhu pada saat percobaan kurang sesuai dengan suhu optimum yang dibutuhkan tanaman kacang hijau, hal ini dapat disebabkan karena ketinggian lahan yang digunakan untuk percobaan tergolong dataran medium dengan ketinggian 763 mdpl. Kacang hijau masih dapat tumbuh dan berproduksi dengan baik di dataran rendah sampai $500 \mathrm{mdpl}$. Di daerah dengan ketinggian 750 mdpl keatas masih dapat tumbuh dengan baik,namun hasil produksinya cenderung rendah.

Kelembaban udara rata-rata selama percobaan mulai dari bulan Mei 2014 adalah 80 \%, bulan Juni $82 \%$, dan bulan Juli sebesar $81 \%$. Kelembaban yang dikehendaki oleh tanaman kacang hijau adalah 50-89 \%. Kelembaban pada saat percobaan cenderung cocok dengan kelembaban yang dikehendaki oleh tanaman kacang hijau, sebab apabila suhu terlalu tinggi maka akanmemengaruhi penyebaran penyakit.

Hama yang menyerang pertanaman kacang hijau antara lain belalang (Valanga nigricornis Burn.), kepik cokelat (Riptorus linearis F.), hama penggerek polong (Maruca testulallis) dan ulat jengkal (Chrysodeixis chalcites). Belalang pada umumnya memakan daun dan cabang hingga patah akibat gigitannya, serangan belalang terjadi pada saat tanaman berumur sekitar 3-5 mst. Gejala serangan belalang menyebabkan daun berlubang, rata-rata serangan tergolong rendah dengan intensitas sebesar $5 \%$ sehingga tidak menimbulkan kerusakan yang berarti.

Serangan kepik coklat terjadi pada awal fase generatif sampai panen yaitu 4-6 mst, gejala yang disebabkan oleh serangan kepik coklat adalah pertumbuhan polong dan perkembangan biji terhambat sehingga polong dan biji kempes kemudian polong mengering dan akhirnya gugur. Serangan pada fase pengisian biji menyebabkan biji berwarna hitam dan busuk, sedangkan pada fase pematangan polong menyebabkan biji keriput. Rata-rata serangan kepik coklat sebesar $16 \%$ dan terjadi pada saat pengisian polong yang menyebabkan banyaknya polong hampa pada tanaman.

Serangan hama yang memengaruhi kualitas maupun kuantitas produksi tanaman kacang hijau adalah hama penggerek polong (Maruca testulallis) yang menyerang pada saat masa pematangan polong atau pada umur 5-8 mst. Polong yang terserang akan terdapat lubang-lubang bulat kecil, bijinya habis dimakan dan larva biasanya terdapat di dalam polong. Serangan hama penggerek polong ini mencapai $25 \%$. Pengendalian hama 
penggerek polong ini dengan cara mengambil lalu memusnahkan larva telur dan imago serta dengan pengendalian kimiawi menggunakan insektisida Curacron 500 EC pada 4 mst dan 6 mst.

Serangan ulat jengkal (Chrysodeixis chalcites) pada tanaman kacang hijau menyebabkan bercakbercak putih pada daun dan menyebabkan daun terserang habis dan hanya tinggal beberapa tulang daunnya saja. Intensitas serangan larva ulat jengkal sebesar $10 \%$. Serangan ulat jengkal terjadi pada stadia vegetatif dan generatif, larva ulat jengkal aktif pada malam hari dan berpindah tempat. Pengendalian hama ini adalah dengan mengambil lalu memusnahkan ulat yang ditemukan di lahan percobaan.

Penyakit yang menyerang tanaman kacang hijau adalah bercak daun yang disebabkan oleh cendawan Cercospora sinensis dan penyakit embun tepung atau powdery mildew yang disebabkan oleh cendawan Oidium sp. Pada awal serangan penyakit bercak daun terjadi pada daun tua, lalu bercak menyebar ke seluruh daun, ukuran bercak berbentuk bulat dan tidak beraturan dan menyerang pada saat tanaman berumur 5-8 mst dengan rata-rata luas serangan $38 \%$. Gejala penyakit embun tepung dapat dilihat dari permukaan daun, batang, dan polong. Penyakit ini sangat berpengaruh pada proses fotosintesis tanaman dan pada lahan percobaan penyakit hanya menyerang pada bagian daun saja. Tanda tanaman yang terserang penyakit embun tepung yaitu adanya tepung yang berwarna putih yang merupakan miselium, penyakit ini menginfeksi pada umur 5-8 mst dengan rata-rata luas serangan $24 \%$. Pengendalian dilakukan dengan menggunakan fungisida Dithane M-45 pada saat 5 mst.

Gulma yang dominan tumbuh selama percobaan adalah Jampang pahit (Paspalum conjugatum), Rumput teki (Cyperus rotundus), putri malu (Mimosa pudica), dan Bayam-bayaman (Amaranthus spinosus). Gulma tersebut tumbuh di sekitar pertanaman sejak tanaman berumur $1 \mathrm{mst}$ hingga tanaman memasuki tahap generatif. Pengendalian gulma yang dilakukan pada percobaan ini yaitu dengan pengendalian secara mekanis dan manual denganmencabut gulma yang tumbuh dengan menggunakan tangan dan kored. Penyiangan dilakukan selama 2 minggu sekali apabila dilihat lahan sudah banyak ditumbuhi oleh gulma, penyiangan tersebut diharapkan dapat mengurangi adanya perebutan unsur hara pada saat awal fase vegetatif.
Tinggi tanaman merupakan indikator pertumbuhan yang digunakan untuk mengukur pengaruh lingkungan atau perlakuan yang diterapkan, karena tinggi tanaman merupakan ukuran pertumbuhan yang paling mudah dilihat (Sitompul dan Guritno, 1995).

Berdasarkan hasil statistik pada Tabel 1 diketahui bahwa pada umur 2 dan 4 mst penambahan pupuk $\mathrm{P}$ dan pupuk organik cair tidak berbeda nyata pada setiap perlakuan pada pengamatan 2 dan 4 mst. Pada umur $6 \mathrm{mst}$ perlakuan $\mathrm{F}$ memberikan pengaruh yang berbeda nyata terhadap perlakuan $\mathrm{C}$ dan $\mathrm{E}$ namun tidak berbeda nyata dengan perlakuan A, B, D, G, H, I.

Tabel 1. Pengaruh Penambahan Pupuk $P$ dan Pupuk Organik Cair terhadap Komponen Pertumbuhan.

\begin{tabular}{|c|c|c|c|c|}
\hline \multirow[t]{2}{*}{ Perlakuan } & \multicolumn{3}{|c|}{ "Tinggi Tanaman (cm) } & \multirow{2}{*}{$\begin{array}{c}\text { Indeks } \\
\text { Luas } \\
\text { Daun }\end{array}$} \\
\hline & $2 \mathrm{mst}$ & $4 \mathrm{mst}$ & $6 \mathrm{mst}$ & \\
\hline $\bar{A}$ & $5,93 \mathrm{a}$ & $3,83 \mathrm{a}$ & $15,46 \mathrm{abc}$ & $3,83 \mathrm{a}$ \\
\hline B & $6,33 \mathrm{a}$ & 3,98 a & $15,43 \mathrm{abc}$ & 3,98 a \\
\hline C & $5,92 \mathrm{a}$ & $4,61 \mathrm{ab}$ & $13,90 \mathrm{a}$ & $4,61 \mathrm{ab}$ \\
\hline $\mathrm{D}$ & $6,14 \mathrm{a}$ & $4,09 \mathrm{a}$ & $15,70 \mathrm{abc}$ & $4,09 \mathrm{a}$ \\
\hline $\mathrm{E}$ & $5,72 \mathrm{a}$ & $4,17 \mathrm{a}$ & $14,83 \mathrm{ab}$ & $4,17 \mathrm{a}$ \\
\hline $\mathrm{F}$ & $6,08 \mathrm{a}$ & $4,88 \mathrm{abc}$ & $19,46 \mathrm{c}$ & $4,88 \mathrm{abc}$ \\
\hline G & $5,58 \mathrm{a}$ & $3,75 \mathrm{a}$ & $17,60 \mathrm{abc}$ & $3,75 \mathrm{a}$ \\
\hline $\mathrm{H}$ & $5,55 \mathrm{a}$ & $5,60 \mathrm{bc}$ & $16,40 \mathrm{abc}$ & $5,60 \mathrm{bc}$ \\
\hline I & $5,63 \mathrm{a}$ & $6,13 \mathrm{c}$ & $18,63 \mathrm{bc}$ & $6,13 \mathrm{c}$ \\
\hline
\end{tabular}

Keterangan : Angka-angka yang diikuti dengan huruf yang sama pada kolom yang sama tidak berbeda nyata pada uji Duncan $5 \%$.

Hasil percobaan menunjukkan tinggi tanaman lebih rendah dari deskripsi tanaman hal ini disebabkan karena kandungan bahan organik tanah terutama kandungan C-organik yang rendah. Kandungan C-organik dalam tanah percobaan sebesar 1,16 padahal sebaiknya kandungan C-organik tidak boleh kurang dari 2. Fosfat penting dalam proses pembelahan jaringan meristem. Pada tanah percobaan yang cenderung masam, kemungkinan terjadinya fiksasi $\mathrm{P}$ oleh $\mathrm{Fe}$ menjadi semakin besar (Aisyah dkk., 2006). Jika P meningkat maka akan turut pula meningkatkan pembelahan sel yang dapat berpengaruh terhadap tinggi tanaman (Mosse, 1981).

Berdasarkan hasil analisis statistik pada Tabel 1 diketahui bahwa penambahan pupuk $\mathrm{P}$ dan pupuk organik cair menunjukkan pengaruh yang tidak berbeda nyata antar perlakuan A, B, 
$\mathrm{C}, \mathrm{D}, \mathrm{E}, \mathrm{F}, \mathrm{G}$ dan $\mathrm{H}$ namun memberikan pengaruh yang nyata terhadap perlakuan $\mathrm{I}$.

Indeks luas daun merupakan parameter yang menunjukan potensi tanaman untuk melakukan proses fotosintesis dan produktivitas di lapangan. Menurut Goldsworthy dan Fisher (1992), beberapa hal yang memengaruhi besarnya ILD adalah kerapatan tanaman dan penyediaan hara terutama penyediaan unsur nitrogen yang sangat memengaruhi besarnya luas daun. Unsur $\mathrm{N}$ dapat meningkatkan pertumbuhan tanaman dan luas daun (Gardner dkk, 1991).

Berdasarkan hasil analisis statistik pada Tabel 2 diketahui bahwa penambahan pupuk $\mathrm{P}$ dan pupuk organik cair terhadap cabang produksi menunjukan pengaruh tidak nyata pada setiap perlakuan terhadap cabang produktif. Perlakuan F cenderung menunjukan nilai cabang produktif yang lebih besar namun tidak berbeda nyata dengan perlakuan lainnya. Cabang produktif adalah cabang dari batang pada tanaman yang menghasilkan bunga yang kemudian menjadi bakal biji atau buah. Salah satu faktor yang memengaruhi pertumbuhan dan perkembangan cabang produktif adalah unsur hara.Tidak adanya perbedaan yang nyata pada setiap perlakuan diduga karena unsur hara $\mathrm{P}$ dari pupuk fosfor kurang efektif diserap oleh tanaman pada masa awal fase generatif.

Berdasarkan hasil analisis statistik pada Tabel 2 diketahui bahwa penambahan pupuk $\mathrm{P}$ dan pupuk organik cair menunjukan pengaruh yang tidak berbeda nyata antar perlakuan terhadap jumlah polong isi per tanaman. Pengaruh pemberian pupuk $\mathrm{P}$ dan pupuk organik cair belum mampu meningkatkan jumlah polong isi secara signifikan, hal ini disebabkan karena adanya faktor penyerapan unsur hara yang kurang akibat sukar larutnya unsur $\mathrm{P}$ dalam tanah sehingga proses pembentukan biji tidak maksimal. Penyebab sukar larutnya $\mathrm{P}$ dipengaruhi oleh rendahnya curah hujan pada masa pembentukan biji yaitu dengan rata-rata hanya $3,5 \mathrm{~mm}$.

Berdasarkan hasil analisis statistik pada Tabel 2 diketahui bahwa penambahan pupuk $\mathrm{P}$ dan pupuk organik cair menunjukan pengaruh yang tidak berbeda nyata antar perlakuan namun pada perlakuan $\mathrm{E}$ dan $\mathrm{H}$ memberikan pengaruh yang nyata namun. Jenis tanaman kacang-kacangan sebagian besar kehilangan polong-polong mudanya setelah proses penyerbukan. Kehilangan polong tersebut dapat mengurangi hasil potensial jika dibandingkan kalau struktur-struktur tersebut tidak hilang atau hampa. Selain itu dalam percobaan di lapangan, kehilangan hasil dapat diakibatkan karena adanya gangguan dari hama penggerek polong dengan serangan mencapai $25 \%$.

Tabel 2. Pengaruh Penambahan Pupuk $P$ dan Pupuk Organik Cair terhadap Komponen Hasil.

\begin{tabular}{cccccc}
\hline \hline $\begin{array}{c}\text { Perla- Jumlah } \\
\text { kuan }\end{array}$ & $\begin{array}{c}\text { Jumlah } \\
\text { Produkif }\end{array}$ & $\begin{array}{c}\text { Polong } \\
\text { Isi }\end{array}$ & $\begin{array}{c}\text { Jumlah } \\
\text { Polong } \\
\text { Hampa }\end{array}$ & $\begin{array}{c}\text { Jumlah } \\
\text { Biji Per } \\
\text { Polong }\end{array}$ & $\begin{array}{c}\text { Rata-rata } \\
\text { Bobot 100 } \\
\text { Butir (g) }\end{array}$ \\
\hline $\mathrm{A}$ & $3,73 \mathrm{a}$ & $6,6 \mathrm{a}$ & $1,60 \mathrm{ab}$ & $7,32 \mathrm{a}$ & $5,43 \mathrm{a}$ \\
$\mathrm{B}$ & $3,73 \mathrm{a}$ & $7,2 \mathrm{a}$ & $0,60 \mathrm{ab}$ & $7,66 \mathrm{ab}$ & $5,73 \mathrm{ab}$ \\
$\mathrm{C}$ & $3,86 \mathrm{a}$ & $9,4 \mathrm{a}$ & $1,60 \mathrm{ab}$ & $8,13 \mathrm{ab}$ & $6,10 \mathrm{~b}$ \\
$\mathrm{D}$ & $3,53 \mathrm{a}$ & $8,7 \mathrm{a}$ & $0,86 \mathrm{ab}$ & $8,85 \mathrm{ab}$ & $5,92 \mathrm{ab}$ \\
$\mathrm{E}$ & $3,73 \mathrm{a}$ & $6,1 \mathrm{a}$ & $0,46 \mathrm{a}$ & $9,33 \mathrm{~b}$ & $5,59 \mathrm{ab}$ \\
$\mathrm{F}$ & $4,26 \mathrm{a}$ & $9,0 \mathrm{a}$ & $0,86 \mathrm{ab}$ & $8,84 \mathrm{ab}$ & $5,69 \mathrm{ab}$ \\
$\mathrm{G}$ & $3,60 \mathrm{a}$ & $7,0 \mathrm{a}$ & $1,06 \mathrm{ab}$ & $8,85 \mathrm{ab}$ & $5,46 \mathrm{a}$ \\
$\mathrm{H}$ & $4,00 \mathrm{a}$ & $9,2 \mathrm{a}$ & $4,00 \mathrm{~b}$ & $9,03 \mathrm{ab}$ & $5,68 \mathrm{ab}$ \\
$\mathrm{I}$ & $3,73 \mathrm{a}$ & $8,1 \mathrm{a}$ & $3,53 \mathrm{ab}$ & $7,79 \mathrm{ab}$ & $5,50 \mathrm{a}$ \\
\hline \hline
\end{tabular}

Keterangan : Angka-angka yang diikuti dengan huruf yang sama pada kolom yang sama tidak berbeda nyata pada uji Duncan $5 \%$.

Berdasarkan hasil analisis statistik pada Tabel 2 diketahui bahwa penambahan pupuk P dan pupuk organik cair menunjukan pengaruh yang tidak berbeda nyata antar perlakuan namun pada perlakuan A adan E memberikan pengaruh yang nyata. Faktor penentu jumlah biji sangat kompleks, diantaranya adalah faktor lingkungan. Faktor lingkungan berpengaruh pada laju perkembangan terutama suhu dan laju pertumbuhan yaitu penyinaran yang bergabung untuk menentukan jumlah biji dari setiap polong yang pada akhirnya akan dipanen.

Berdasarkan hasil analisis statistik pada Tabel 2 diketahui bahwa penambahan pupuk $\mathrm{P}$ dan pupuk organik cair menunjukan pengaruh yang tidak berbeda nyata antar perlakuan namun pada perlakuan $C$ memberikan pengaruh yang nyata terhadap perlakuan $A, G$, dan I. Adanya penuaan pada tanaman serta serangan hama menyebabkan penyerapan air, unsur hara dan fotosintesis menjadi terbatas, sehingga perkembangan polong dan biji menjadi terhambat (Dwijoseputro, 1990). Ukuran polong yang kecil menghasilkan biji yang kecil pula, sehingga berat biji menjadi relatif kecil dan rata-rata bobot 100 biji menjadi tidak berbeda.

Berdasarkan hasil analisis statistik pada Tabel 3 diketahui bahwa penambahan pupuk $P$ dan pupuk organik menunjukan pengaruh yang tidak berbeda nyata antar perlakuan terhadap bobot biji per tanaman. Namun perlakuan $\mathrm{H}$ 
cenderung menunjukan nilai bobot kering tanaman yang lebih besar namun tidak berbeda nyata dengan perlakuan lainnya.Pengaruh perlakuan pupuk $\mathrm{P}$ dan pupuk organik cair terhadap bobot biji per tanaman tidak berbeda nyata dapat disebabkan karena tanaman kurang suplai karbohidrat hasil fotosintesis dan hanya sedikit yang dapat dimanfaatkan untuk pengisian buah (Theodore and Plaxton, 1993).

Tabel 3. Pengaruh Penambahan Pupuk $P$ dan Pupuk Organik Cair Terhadap Hasil.

\begin{tabular}{ccll}
\hline \hline Perlakuan & $\begin{array}{c}\text { Bobot Biji } \\
\text { per } \\
\text { Tanaman }\end{array}$ & $\begin{array}{c}\text { Bobot Biji } \\
\text { per Petak }\end{array}$ & $\begin{array}{c}\text { Indeks } \\
\text { Panen }\end{array}$ \\
\hline $\mathrm{A}$ & $3,00 \mathrm{a}$ & $228,78 \mathrm{ab}$ & $1,26 \mathrm{ab}$ \\
$\mathrm{B}$ & $3,62 \mathrm{a}$ & $228,70 \mathrm{ab}$ & $0,68 \mathrm{a}$ \\
$\mathrm{C}$ & $4,07 \mathrm{a}$ & $298,68 \mathrm{~b}$ & $1,05 \mathrm{ab}$ \\
$\mathrm{D}$ & $4,33 \mathrm{a}$ & $228,79 \mathrm{ab}$ & $0,72 \mathrm{ab}$ \\
$\mathrm{E}$ & $2,94 \mathrm{a}$ & $172,32 \mathrm{a}$ & $1,38 \mathrm{~b}$ \\
$\mathrm{~F}$ & $4,25 \mathrm{a}$ & $262,08 \mathrm{ab}$ & $0,74 \mathrm{ab}$ \\
$\mathrm{G}$ & $3,02 \mathrm{a}$ & $155,26 \mathrm{a}$ & $0,77 \mathrm{ab}$ \\
$\mathrm{H}$ & $4,53 \mathrm{a}$ & $227,02 \mathrm{ab}$ & $0,88 \mathrm{ab}$ \\
$\mathrm{I}$ & $3,53 \mathrm{a}$ & $227,46 \mathrm{ab}$ & $1,11 \mathrm{ab}$ \\
\hline \hline
\end{tabular}

Keterangan : Angka-angka yang diikuti dengan huruf yang sama pada kolom yang sama tidak Berbeda nyata pada uji Duncan $5 \%$.

Berdasarkan hasil analisis statistik pada Tabel 3 diketahui bahwa penambahan pupuk $\mathrm{P}$ dan pupuk organik menunjukan pengaruh yang tidak berbeda nyata antar perlakuan terhadap bobot biji per petak. Namun pada perlakuan C memberikan pengaruh yang nyata terhadap perlakuan E dan G. Hasil bobot biji per petak yang rendah dapat dipengaruhi oleh ketinggian tempat, tempat yang digunakan pada percobaan termasuk dataran medium, sedangkan biasanya untuk varietas Vima-1 ditanam di dataran rendah dengan tinggi sekitar $550 \mathrm{mdpl}$. Sehingga menyebabkan panen mengalami keterlambatan dan panen tidak serempak, jika pada deskripsi tanaman waktu panen sekitar 57-60 hari tetapi saat di lapangan waktu panen 80 hari dengan waktu berbunga 2 kali secara bertahap.

Berdasarkan hasil analisis statistik pada Tabel 3 diketahui bahwa penambahan pupuk $\mathrm{P}$ dan pupuk organik menunjukan pengaruh yang tidak berbeda nyata antar perlakuan terhadap bobot biji per petak. Namun pada perlakuan D menunjukkan angka lebih besar jika dibandingkan dengan perlakuan lainnya. Berpengaruh tidak nyatanya perlakuan POC yang diberikan terhadap berat kering tanaman disebabkan curah hujan yang rendah, maka ketersediaan air bagi tanaman kurang memenuhi kebutuhan tanaman sehingga POC yang diberikan tidak dapat tersuplai dengan baik. Ketersediaan air berkurang mengakibatkan penurunan pertumbuhan tanaman. Menurut Jumin (1988) bahwa fungsi air bagi tanaman sebagai bahan yang penting dalam proses fotosintesis dan pengangkutan.

\section{Kesimpulan dan Saran}

Berdasarkan hasil penelitian maka diperoleh kesimpulan sebagai berikut:

1. Terdapat pengaruh dosis pupuk $\mathrm{P}$ dan pupuk organik cair memberikan pengaruh terhadap pertumbuhan kacang hijau yaitu tinggi tanaman pada 6 mst dan indeks luas daun, sedangkan untuk pengamatan komponen hasil dan hasil memberikan pengaruh pada jumlah polong hampa, jumlah biji per polong, rata-rata bobot 100 butir, bobot biji per petak dan indeks panen.

2. Pemberian dosis pupuk $\mathrm{P}$ dan pupuk organik cair dengan dosis $50 \mathrm{~kg}$ SP-36 ha-1 + $8 \mathrm{~L}^{2} \mathrm{ha}^{-1}$ POC memberikan pengaruh lebih baik terhadap bobot biji per per petak yaitu sebesar 298,68 g/petak atau 0,99 ton/ha.

Saran perbaikan pada pelaksanaan penelitian ini antara lain :

1. Perlu adanya penelitian lebih lanjut pada varietas kacang hijau lainnya dengan jenis tanah yang berbeda dengan menggunakan dosis pupuk $\mathrm{P}$ dan organik cair yang sama untuk melihat perbandingan pertumbuhan dan hasil.

2. Perlu adanya pengamatan data curah hujan sebelum tanam sehingga dapat diketahui waktu yang cocok untuk menanam kacang hijau di lahan kering.

\section{Ucapan Terima Kasih}

Penelitian ini dibiayai oleh Fakultas Pertanian Universitas Padjadjaran melalui skema Hibah Kompetitif Fakultas Pertanian 2014. 


\section{Daftar Pustaka}

Aisyah D, T. Kurniatin, S. Mariam, B. Joy, M. Damayanti, T. Syammusa, N. Nurlaeni, A. Yuniarti, E. Trinurani, dan Y. Machfud. 2006 . Kesuburan Tanah dan Pemupukan. RR Print. Bandung.

Dwidjoseputro, D. 1990. Pengantar Fisiologi Tumbuhan. Gramedia Pustaka Utama. Jakarta.

Gardner, F.P., R.B. Pearce dan R.L. Mitchell. 1991. Fisiologi Tanaman Budidaya. (Penerjemah Herawati S). UI Press. Jakarta.

Goldsworthty, P.R. dan N.M Fisher. 1996. Fisiologi Tanaman Budidaya Tropik (Penerjemah Tohari). GMU Press. Yogyakarta.

Hartatik, W., dan D. Setyorini. 2012. Pemanfaatan pupuk organik untuk meningkatkan kesuburan tanah dan kualitas tanaman. Diakses pada http://balittanah.litbang. deptan.go.id tanggal 19 Februari 2014.

Jumin, H.B. 1988. Ekologi Tanaman. Rajawali Press. Jakarta
Mitra, S., S.K. Rhattacharya, M. Datta and S. Banik. 1999. Effect of variety, rock phosphate and phosphate solubilizing bacteria on growth and yield of green gram in acid soils of Tripura. Environmental Economics 17: 926-930.

Mosse, B. 1981. Vasicular Arbuscular Mycorrhiza Research for Tropical Agriculture. Institute of Tropical Agriculture and Human Resources University of Hawaii. Hawaii.

Renasari, Novita, Priyono., Aryantoro, dan Hadi. 2013. Pengaruh jenis bahan organik dan konsentrasi pupuk organik cair terhadap pertumbuhan dan hasil tanaman kacang hijau. Diakses pada http://ejournal. unisridigilib.ac.id tanggal 27 Maret 20

Sitompul, M dan B. Guritno.1995. Analisis Pertumbuhan Tanaman. Gadjah Mada University Press. Yogyakarta.

Theodore M.E. and W.C Plaxton. 1993. Metabolic adaptations of plant respiration to nutritional phosphate deprivation. Plant Physiol. 101: 339-344. 